\title{
Types and Location of Nigerian Universities
}

\author{
Emmanuel Mogaji \\ University of Greenwich, London, UK \\ e.o.mogaji@greenwich.ac.uk
}

\begin{abstract}
Marketing higher education in Africa is a growing research domain, and there is a shortage of knowledge about how higher education in Africa are marketing themselves towards prospective students. Despite inadequate funding for the existing tertiary institutions, there are growing numbers of Universities to meet the quest of students for higher education. Understanding the size and key stakeholders in this market is for both administrative and research purposes. Likewise, it is essential for strategic planning and developing effective marketing communications strategies. The paper presents an overview of Universities structure in Nigeria, recognising the different classification of the public and private Universities. The number of Universities across different states and geo-political zones are presented. The analysis offers both theoretical and practical implications for researchers, University managers and policymakers
\end{abstract}

Keywords: Nigeria, Universities, Public, Private, State Federal, Marketing, Typology

\section{Introduction}

Marketing higher education in Africa is a growing research domain, and there is a dearth of knowledge about how higher education in Africa are marketing themselves towards prospective students (Mogaji, et al., 2017). Despite inadequate funding for the existing tertiary institutions, there are growing numbers of Universities to meet the quest of students for higher education. Understanding the size and key stakeholders in this market is for both administrative and research 
purposes. Likewise, it is essential for strategic planning and developing effective marketing communications strategies.

While recognising there are many countries in the continent with different universities, and this study focuses explicitly on Nigeria - perhaps an understanding of the Nigerian University system can serve as a starting point for research into other countries' university system. Nigeria is the most populous country in Africa, with a population of over 200 million and the median age of 17.9 years, it has the largest higher education market in sub-Saharan Africa, and there is a growing demand.

With this considerable size of Nigeria comes the challenges of educating her citizens. The demand for higher education is very high, yet the supply is little. The public universities are not meeting these demands, and this has led to high numbers of Private Universities aspiring to reach this market needs. This paper aims to documents the number of Universities in Nigeria, their founding structure and location within the country. This paper offers a theoretical contribution toward understanding the higher education market and its implication for marketing practices.

\section{Higher Education in Nigeria}

The National Policy on Education (NPE) in Nigeria is the provides national guideline for the effective administration, management and implementation of education at all tiers of government. The policy acknowledges the advantage of ample conditional provision and legislative support for stakeholders to participate in the delivery of education at all levels, allowing Private sector, Individuals, Civil Society Organisation (CSO) and Non-Governmental Organisation are very active in the sector (NERDC, 2013). The education system is structured into:

- Early Child development aged 0-4.

- Basic Education aged 5 -15 years which includes one year of Pre-Primary, six years of Primary Education and three years of Junior Secondary Education.

- Post -Basic Education of 3 years in Secondary Schools, Technical Colleges and

- Tertiary Education provided in Colleges of Education, Monotechnics, Polytechnics and the Universities.

There have often been mixed reactions concerning the issue of university education in Nigeria and how this can be compared to what is obtainable in other countries of the world. (Iruonagbe, et al., 2015). A status report on Higher 
education in Nigeria argued that political interventions in the higher education system under a series of military governments have distorted and constrained the development of Higher education in Nigeria (Saint, et al., 2003).

The National Universities Commission of Nigeria is a government agency saddled with the responsibility of promoting quality higher education in Nigeria; The Commission is also responsible for approving all academic programs run in Nigerian universities and approving the establishment of all higher educational institutions offering degree programs. Nigeria's University education system includes both Public and Private Universities. As illustrated in Figure 1, Public Universities are run by both Federal and State Governments while the Private Universities are owned by different religious bodies, Individuals and organisation.

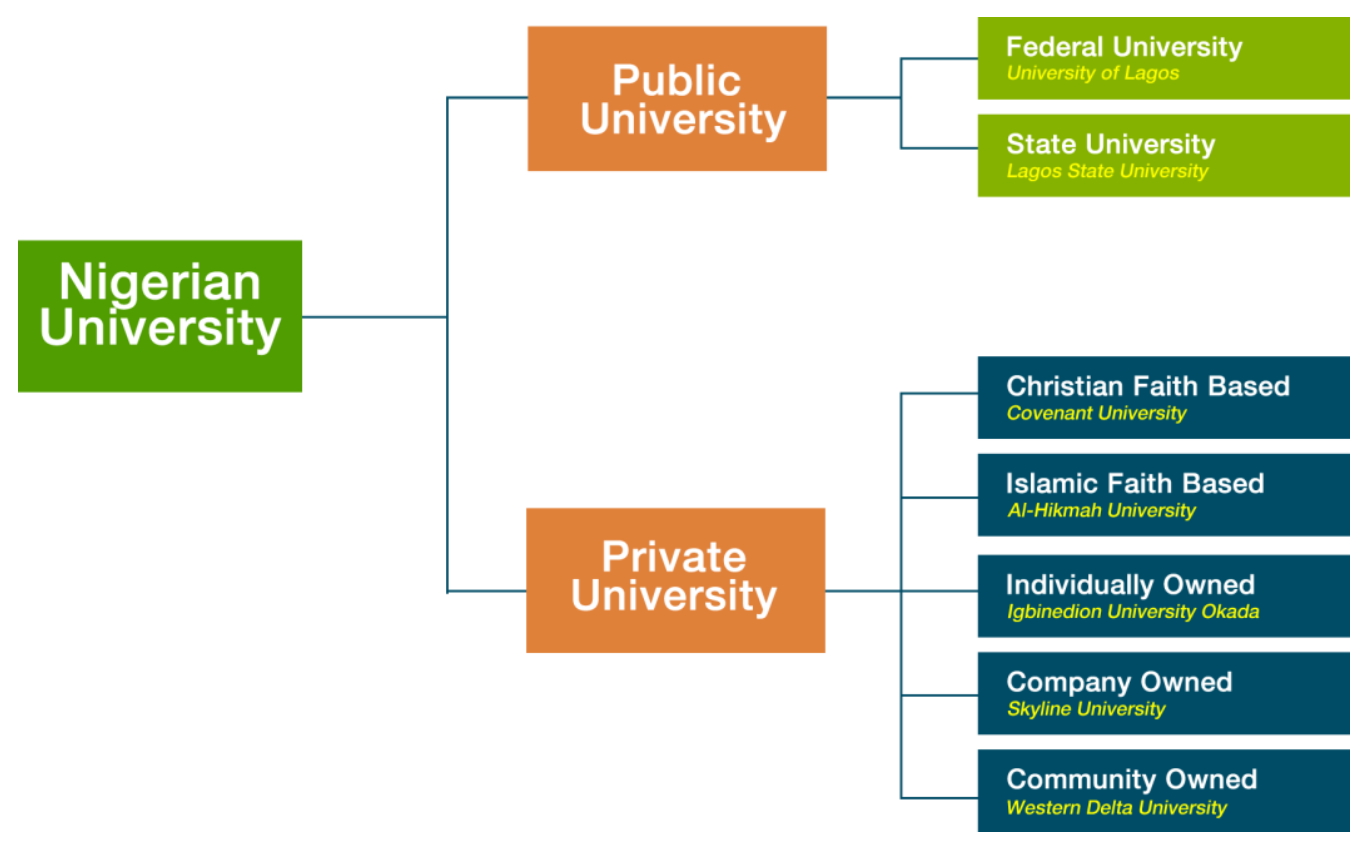

Figure 1: Ownership Classification of Universities in Nigeria.

According to the information available on the NUC websites as of August $1^{\text {st }}, 2019$, there are currently 174 approved universities in Nigeria. As presented in Table 1, it comprises of 43 Federal Universities, 52 State Universities and 79 Private Universities (NUC, 2019). Figure 2 illustrates the location of all these Universities across the country.

Table 1: Universities in Nigeria

\begin{tabular}{ccccc}
\hline & Federal & State & Private & Total \\
\hline Universities & 43 & 52 & 79 & 174 \\
\hline
\end{tabular}




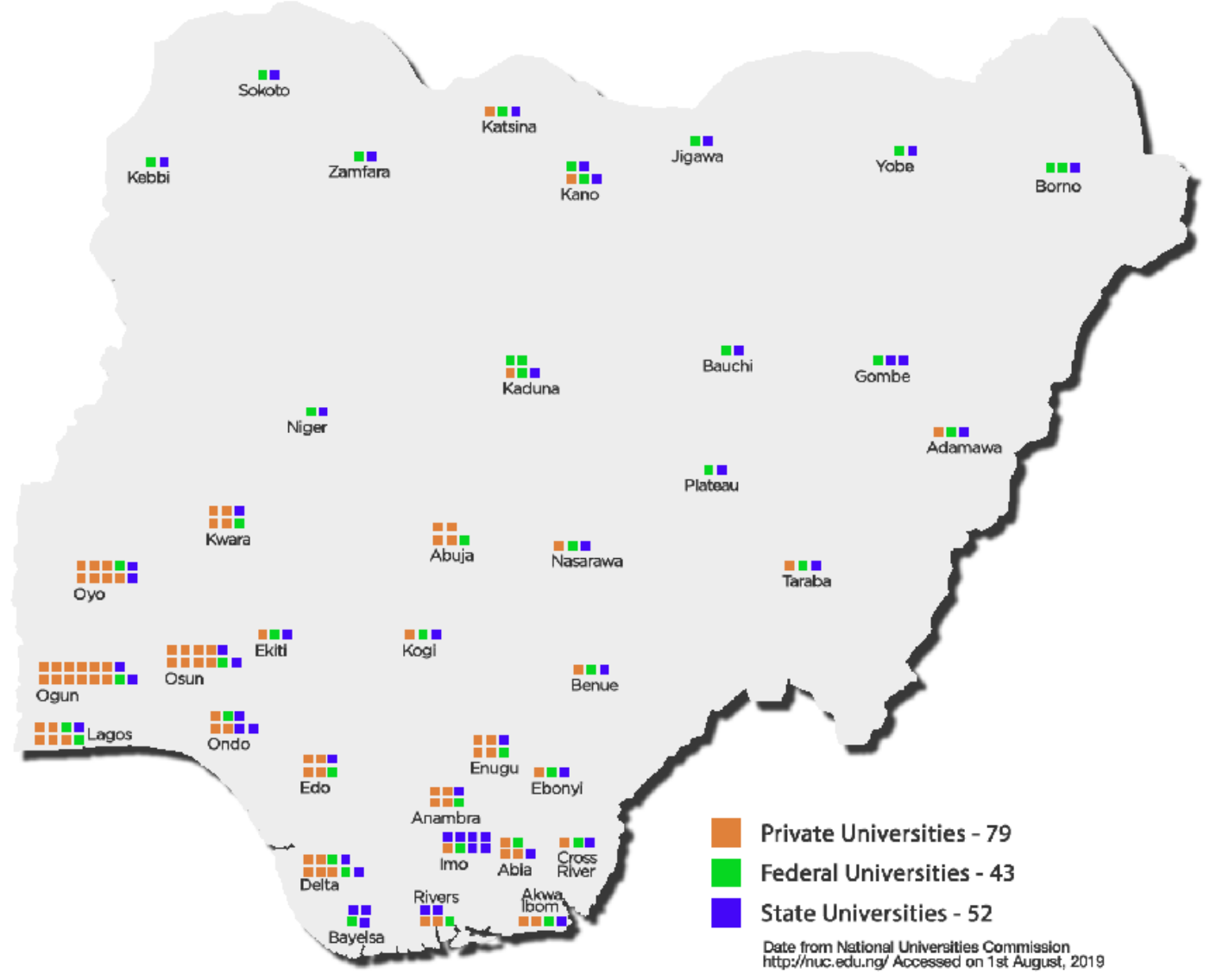

Figure 2: Location of Private, Federal and State Universities across Nigeria.

\section{Public Universities in Nigeria}

Public Universities in Nigeria were established and managed by the Government. The public Universities have continually dominated the higher education landscape in Nigeria for several decades. Unlike Private Universities, Public Universities are located across the country; each state in the country can boast of a University. Public Universities are cheaper, affordable for students across the country and has different courses which may not be available in the public Universities. There is often a sense of pride in attending a public university as students feel they are matured to deal with the challenges that come their way unlike those in private school who often/The social life at the public Universities, unlike the strict in public Universities has often attracted prospective students to the public Universities.

These public universities are either Federal Universities or State Universities. 


\section{Federal Universities}

These are often considered some of the most prestigious Universities in Nigeria. The Federal Government of Nigeria founded these Universities, and strategically located across the country to give access to Education. There is an effort to establish Federal Universities in each state of the Country. These Universities are often more funded than the state Universities, and they are under the control of the Federal Ministry of Education. The President of Nigeria is the Visitor of all Federal Universities though not usually involved in the management process of the institution. The first of these universities is the University of Ibadan established in 1948. These Federal Universities often created in batches. Despite inadequate funding for the existing tertiary institutions, the Government has created ten new federal institutions are part of the over 80 that the National Assembly is currently working to establish (Krishi, 2018). There are 43 Federal Universities in Nigeria as at August 2019. Figure 3 illustrates the location of all the State Universities in Nigeria. Each square presents a University. Kaduna State, with three universities, has the highest number of federal Universities. This includes the Nigerian Defence Academy and Air Force Institute of Technology which was founded in 2018.

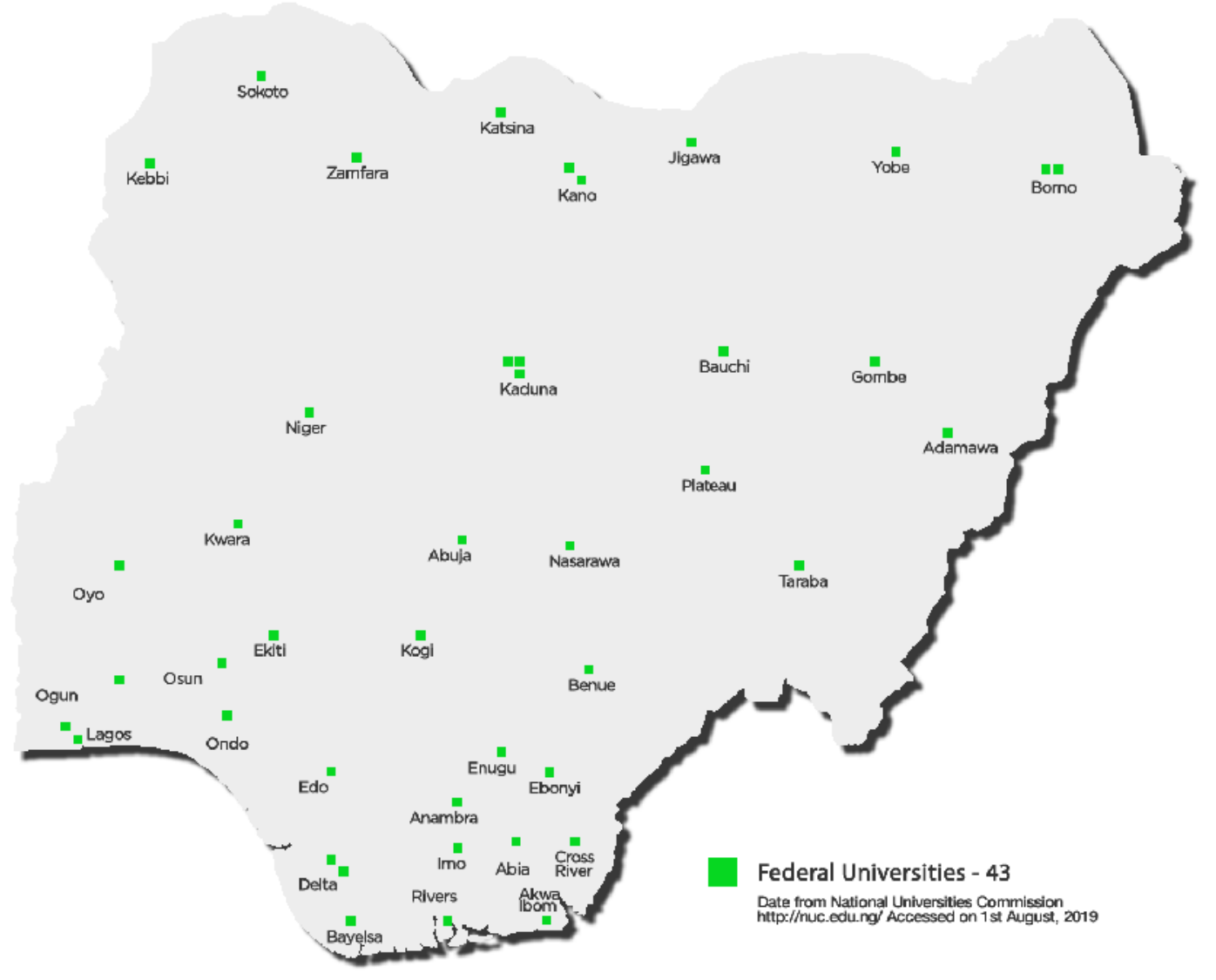

Figure 3: Location of Federal Universities across Nigeria. 


\section{State Universities}

These universities are created by individual states of the country and responsible to the State's Ministry of Education. They are often not well funded, unlike the Federal Universities as this funding depends on education budgetary allocation, which differs across the states. This lack of financing reflects on the quality of their facilities and student experience. The State Governor is the Visitor. The first state University in Nigeria is Enugu State University of Science and Technology with her main campus at Enugu. Despite the inability of the Imo State government to cater to its existing university, the National Universities Commission (NUC) approved four new state-owned universities for Imo States (Adedigba, 2019). There are 52 State Universities in Nigeria as at August 2019. Figure 4 illustrates the location of all the State Universities in Nigeria. Each square presents a University. Imo State, with six universities, has the highest number of State Universities.

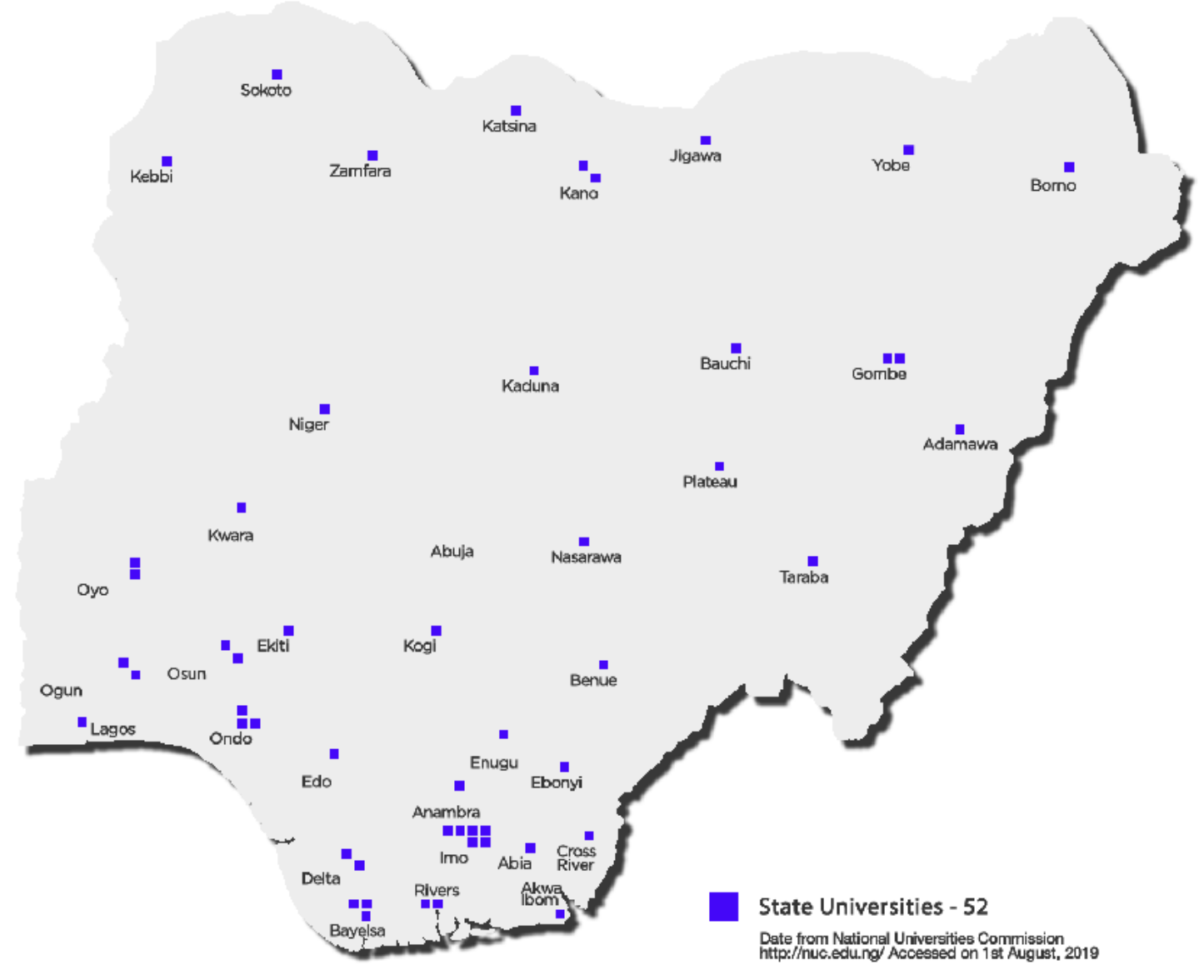

Figure 4: Location of State Universities across Nigeria. 


\section{Private Universities}

Private Universities are non-public or independent universities, solely owned, financed and managed by private individuals, denominational or secular boards; often they are operated for profit. Many issues with the education system in Nigeria has called for the establishment of private universities (Iruonagbe, et al., 2015). The pioneering set of private Universities in Nigeria were approved in 1999 (Ademola, et al., 2014) These Universities are (Babcock at llishan Remo in Ogun State, owned and operated by the Seventh-day Adventist Church; Madonna in Okija, Anambra State, owned by the Catholic Church in Nigeria Catholic, and Igbinedion in Okada, Edo founded by Sir Gabriel Osawaru Igbinedion, a prominent Benin Chief). Since then, private universities have continued to grow in quantity. As at August 2019, there were seventy-nine (79) approved private universities in Nigeria. Figure 5 illustrates the location of all the private Universities in Nigeria. Each square presents a University. Ogun State, with 12 universities, has the highest number of private Universities.

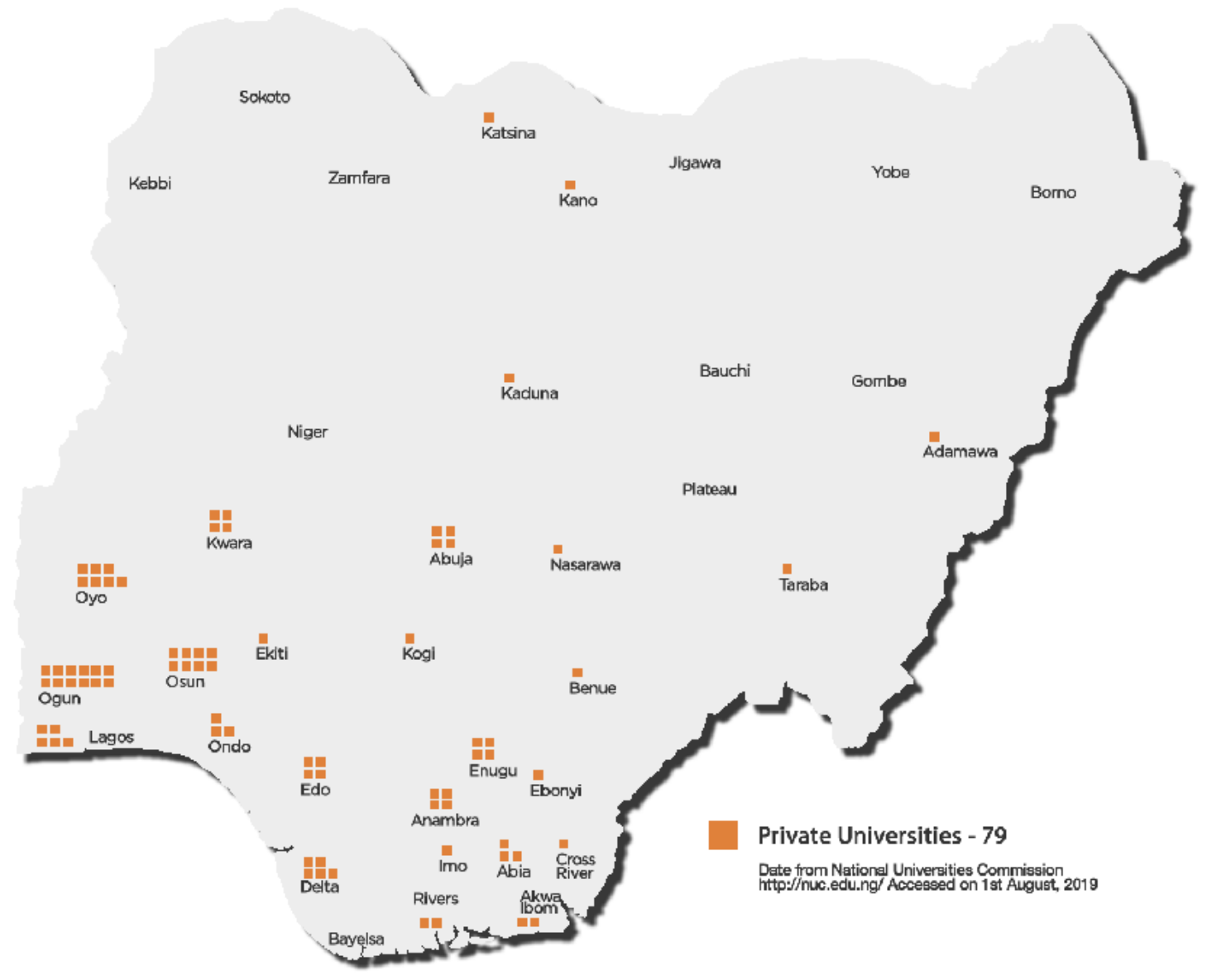

Figure 5: Location of Private Universities across Nigeria. 


\section{Locations of Universities}

The geographical location of these Universities was also accessed. The sites of these Universities highlight an implication for policymakers and organisation interested in creating a University. Nigeria has 36 states and one Federal Capital Territory (FCT) - Abuja. These states are also further classified into a geopolitical zone. There are 6 zones - South West, South-South, North Central, South East, North West and North East. The North West Zone (Jigawa, Kaduna, Kano, Katsina, Kebbi, Sokoto and Zamfara), with ten Universities, has the highest number of Federal universities. South West (Ekiti, Lagos, Ogun, Ondo, Osun and Oyo) has the highest number of State and Private Universities. The Zone has 11 state Universities and 36 Private Universities. A breakdown of these Universities types across the six geological zone is presented in Table 2.

Table 2: Nigerian Universities across the Six Geo-political zones

\begin{tabular}{ccccc}
\hline & Federal & State & Private & Total \\
\hline South West & 7 & 11 & 36 & 54 \\
\hline South-South & 7 & 10 & 14 & 31 \\
\hline North Central & 7 & 6 & 11 & 24 \\
\hline South East & 5 & 10 & 13 & 28 \\
\hline North West & 10 & 8 & 3 & 21 \\
\hline North East & 7 & 7 & 2 & 16 \\
\hline & $\mathbf{4 3}$ & $\mathbf{5 2}$ & $\mathbf{7 9}$ & $\mathbf{1 7 4}$ \\
\hline
\end{tabular}

On an individual state level, All the states in Nigeria, including the FCT, has a Federal University. Likewise, all the state has its own funded University. FCT does not have a state University. Twenty-six states have one state University each, and seven has two states Universities, Bayelsa and Ondo have three state Universities respectively, while Imo state has the highest with six. Eleven states in Nigeria (Niger, Plateau, Bauchi, Borno, Gombe, Yobe, Jigawa, Kebbi, Sokoto Zamfara and Bayelsa) do not have a Private University while 12 states have only One private University. Abuja, the FCT has four private Universities. Oyo State has seven private Universities, Osun State has eight private Universities while Ogun state has the highest number with 12 private Universities. Table 3 presents the breakdown of each state in the geopolitical zones and the numbers of Universities available in each state. 
Table 3: Nigerian Universities across the Geopolitical zones, States and FCT.

\begin{tabular}{|c|c|c|c|c|c|}
\hline $\begin{array}{c}\text { Geopolitical } \\
\text { zone }\end{array}$ & State & Federal & State & Private & Total \\
\hline \multirow[t]{7}{*}{ North Central } & Benue & 1 & 1 & 1 & 3 \\
\hline & Kogi & 1 & 1 & 1 & 3 \\
\hline & Kwara & 1 & 1 & 4 & 6 \\
\hline & Nasarawa & 1 & 1 & 1 & 3 \\
\hline & Niger & 1 & 1 & 0 & 2 \\
\hline & Plateau & 1 & 1 & 0 & 2 \\
\hline & FCT Abuja & 1 & 0 & 4 & 5 \\
\hline \multirow[t]{6}{*}{ North East } & Adamawa & 1 & 1 & 1 & 3 \\
\hline & Bauchi & 1 & 1 & 0 & 2 \\
\hline & Borno & 2 & 1 & 0 & 3 \\
\hline & Gombe & 1 & 2 & 0 & 3 \\
\hline & Taraba & 1 & 1 & 1 & 3 \\
\hline & Yobe & 1 & 1 & 0 & 2 \\
\hline \multirow[t]{7}{*}{ North West } & Jigawa & 1 & 1 & 0 & 2 \\
\hline & Kaduna & 3 & 1 & 1 & 5 \\
\hline & Kano & 2 & 2 & 1 & 5 \\
\hline & Katsina & 1 & 1 & 1 & 3 \\
\hline & Kebbi & 1 & 1 & 0 & 2 \\
\hline & Sokoto & 1 & 1 & 0 & 2 \\
\hline & Zamfara & 1 & 1 & 0 & 2 \\
\hline \multirow[t]{5}{*}{ South East } & Abia & 1 & 1 & 3 & 5 \\
\hline & Anambra & 1 & 1 & 4 & 6 \\
\hline & Ebonyi & 1 & 1 & 1 & 3 \\
\hline & Enugu & 1 & 1 & 4 & 6 \\
\hline & Imo & 1 & 6 & 1 & 8 \\
\hline \multirow[t]{6}{*}{ South-South } & Akwa Ibom & 1 & 1 & 2 & 4 \\
\hline & Bayelsa & 1 & 3 & 0 & 4 \\
\hline & Cross River & 1 & 1 & 1 & 3 \\
\hline & Rivers & 1 & 2 & 2 & 5 \\
\hline & Delta & 2 & 2 & 5 & 9 \\
\hline & Edo & 1 & 1 & 4 & 6 \\
\hline \multirow[t]{6}{*}{ South West } & Ekiti & 1 & 1 & 1 & 3 \\
\hline & Lagos & 2 & 1 & 5 & 8 \\
\hline & Ogun & 1 & 2 & 12 & 15 \\
\hline & Ondo & 1 & 3 & 3 & 7 \\
\hline & Osun & 1 & 2 & 8 & 11 \\
\hline & Oyo & 1 & 2 & 7 & 10 \\
\hline TOTAL & & 43 & 52 & 79 & 174 \\
\hline
\end{tabular}




\section{Conclusion}

The paper presents an overview of Universities structure in Nigeria. Recognising the different classification of the public and private Universities. The analysis provides insight into the spread the private Universities across the country, the variation in the number of Universities across the states and geopolitical zone.

The analysis of the Nigerian universities revealed that there are more Private Universities in Nigerian than Federal Universities, although the combined number of public Universities is still more than the private Universities. Forty-five per cent $(n=79)$ of Universities in Nigeria are Private Universities. These private Universities are, however, more predominantly located in South West $(n=36)$ and SouthSouth $(n=14)$ of the country. There are fewer universities in the North East $(n=2)$ and North East $(n=3)$ of the Country. There are 11 states with no private University.

There are Federal Universities in each of all the states in Nigeria, including the FCT. Likewise, each state as well as its University. These findings show that each state in Nigeria has at least two Universities- One Federal University and one state University. Ogun State has the highest number of Universities in the country with 15 Universities. One federal university, two state universities and 12 private universities. The South-West $(n=54)$ has the highest number of Universities, while North East $(n=16)$ has the lowest quantity of Universities.

This study offers both theoretical and practical implications for researchers, University managers and policymakers.

Firstly, it presents an attempt to analysed and identify the number and locations of Universities in Nigeria, especially highlighting the geopolitical locations of the Universities.

Secondly, it contributes to knowledge about the marketing of higher education in Africa by focusing on Nigeria, which is the most significant higher education sector in Africa. Nigeria is the country with the highest numbers of University in Africa. There are countries in Africa that are witnessing the growing rate of private Universities, and this study can be replicated in other African countries to understand the structure and spread of their Universities.

Thirdly, the analysis highlights the spread of the Universities, which presents implication for policymakers with regards to selecting a location for future Universities. With an effort towards creating access to education across the country, situating the federal Universities becomes an important decision. For states with no private university, ait offers an opportunity to create a University. However, the location may be a limiting factor considering they are predominately 
in the northern part of the country. The government may have to consider initiatives to attract Universities to their geopolitical zone.

Fourthly, the spread of these Universities across the geopolitical zones presents opportunities for Universities to work together for the collective good of the society. An example is the 15 universities in Ogun State coming together to share research and technical expertise. Such groups exist around the world - Golden Triangle in the UK (Universities in London, Oxford and Cambridge) and the Regional Universities Network (RUN) in Australia.

Lastly, if it offers theoretical underpinning for research into higher education in Nigeria and other parts of Africa, the academic presentation of this typology of universities could be applicable in education management or marketing research that explores unique features of different Universities in Nigeria.

The typology also suggests directions for future research. Confirming or extending this typology across other African countries is recommended. South Africa often group their universities into Traditional universities, Comprehensive Universities and Universities of technology, possibly some Universities that are not covered under this typology. Future research and analysis could explore the types of University in a different context such as curriculum (Petroleum Resources, Maritime, Defence and Security, Technology), brand identity (Location Named, Personality Named and founders named) and Generations (Federal universities).

While effort has been made to ensure the accuracy of this report, it is essential to acknowledge that the list of the Universities used for this study was from the NUC official list available on their website and assessed on $1^{\text {st }}$ August 2019. There are possibilities that the number of Universities will increase as many more universities will be approved and added to the list. Likewise, there are possibilities that the number of Universities will decrease due to the reaccreditation of Universities which may not meet the expected standard of the NUC. Irrespective of this, an update to this paper will be required.

\section{References}

Adedigba, A., 2019. Amid questions of funding, state approves new universities. [Online] Available at https://www.universityworldnews.com/post.php?story $=20190510120930219$ [Accessed 18 2019].

Ademola, E. O., Ogundipe, A. T. \& Babatunde, W. T., 2014. Students' enrolment into Tertiary Institutions in Nigeria: The Influence Of The Founder's Reputation-A Case Study. Computing, Information Systems, Development Informatics \& Allied Research Journal, 5(3), pp. 1-28. 
Iruonagbe, C. T., Imhonopi, D. \& Egharevba, M. E., 2015. Higher education in Nigeria and the emergence of private universities. International Journal of Education and Research, 3(2), pp. 49-64.

Krishi, M. A., 2018. Senate passes bills to establish 10 tertiary institutions. [Online] Available at: https://www.dailytrust.com.ng/senate-passes-bills-to-establish-10tertiary-institutions.html [Accessed 55 2019].

Mogaji, E., Farinloye, T. \& Aririguzoh, S. A., 2017. Marketing Higher Education in Africa: A Research Agenda. Kingston University London, Academy of Marketing Marketing of Higher Education SIG.

NERDC, 2013. National Policy on Education. 6th ed. Lagos: National Educational Research and Development Council.

NUC, 2019. Home. [Online] Available at: http://nuc.edu.ng/[Accessed 18 2019]. Saint, W., Hartnett, T. A. \& Strassner, E., 2003. Higher education in Nigeria: A status report. Higher Education Policy, 16(3), pp. 259-281. 